\title{
Flensborg den 24. maj 1943
}

Af Merete Bo Thomsen

Den 19. maj 1943 blev Flensborg udsat for et voldsomt bombardement, hvor 82 blev dræbt og 121 såredes. Af de dræbte tilhørte 24 det danske mindretal i Sydslesvig, som derpå arrangerede sin egen fælles begravelsesceremoni. I sin dagbog skrev én af de deltagende danske præster, K.E. Jordt Jørgensen, om adskillige af de flensborgere, der tillige havde overværet den tyske massebegravelse: »aldrig havde de følt forskellen mellem tysk nazisme og dansk ånd så udpræget som ved denne lejlighed. «1 Men hvori adskilte den danske ceremoni sig fra den tyske, og var der også lighedspunkter? Dette undersøges i den følgende artikel.

\section{Indledning}

Bombardementet den 19. maj 1943 er behandlet i flere aviskronikker, i de brede værker om mindretallets historie og i Flensburg im Luftkrieg 1939-1945. Den efterfølgende begravelse af bombeofrene har derimod kun pådraget sig beskeden historisk interesse. Det betyder, at den følgende undersøgelse primært baserer sig på en række førstehåndsberetninger såsom private notater, erindringer, breve, protokoller og avisartikler, mens den eksisterende historieskrivning hovedsageligt har fundet anvendelse ved afdækningen af de kontekstuelle forhold.

Det primære kildemateriale er præget af de politiske forhold i Tyskland i 1943 og behovet for at udtrykke sig forsigtigt i et totalitært samfund. For eksempel har protokolføreren for Folkerådet, der var de danske foreningers fællesrepræsentation 1939-46, flere gange erstattet et egentligt referat med en kort bemærkning om fortrolige forhandlinger. Protokollerne fra de involverede institutioner omtaler da også kun bombardementet yderst kortfattet og viser ikke, hvilke overvejelser der lå bag begravelsen. Hvad angår de centrale aktører, har deres privatarkiver enten ikke kunnet lokaliseres, været utilgængelige, vist sig mangelfulde eller i bedste fald kortfattede, hvad angår begivenhederne den 24. maj. Tilgængelige brevsamlinger indeholder således ret få breve fra 1943 og ingen med afgørende informationer om begravelsesceremonien. Der er dog fundet relevante breve fra de 
tyske myndigheder og konsulatet i Flensborg, ligesom erindringer og artikler, udgivet af centrale aktører på et senere tidspunkt, har vist sig anvendelige. De grundigste beskrivelser af selve ceremonien er fundet i den danske Flensborg Avis og den tyske Flensburger Nachrichten, som imidlertid på hver sin måde var underlagt en betydelig politisk censur i maj 1943.

Billedet af de to begravelsesceremonier har altså måttet sammenstykkes af en mængde småkilder med varierende udsagnskraft. Endelig er tilbageblevne ubesvarede spørgsmål forsøgt afklaret gennem samtaler med fire deltagere i ceremonien, men desværre må det konstateres, at erindringen om begivenhedernes finere detaljer er gået tabt i de mange mellemliggende år.

\section{De allieredes flyangreb}

Det var amerikanske fly, der den 19. maj 1943 bombede Flensborg. Angrebet var et led i en kampagne mod tyske ubådsværfter og fulgte efter bombardementer af havnene i Wilhelmshaven, Kiel og Emden. I Flensborg udløste 55 bombefly mere end 500 bomber over skibsværftet og de omkringliggende industrivirksomheder, men tilstødende beboelseskvarterer blev også ramt. Godt 1.500 flensborgere blev hjemløse, og 82 mistede livet. De 24 dræbte, der tilhørte den danske folkegruppe, var foruden en 85-årig enke, et gammelt ægtepar, en ældre mand, fire kvinder i den arbejdsdygtige alder, en 16-årig dreng, der netop var gået ud af Duborg-Skolen samt 14 børnehavebørn i alderen to til seks år, fulgt af en syvårig storebror. Han var mødt op i den danske børnehave Ingrid-Hjemmet, der lå i Batterigade, for at afhente sin lillesøster, og da bombealarmen lød, var han fulgt med børnene og de to ledere, Wanda og Martha Radszewski, hen i det anviste beskyttelsesrum. Der var tale om et underjordisk rum, som fungerede som tilflugt for medarbejderne ved en fiskekonservesfabrik og en chokoladefabrik, men også for lokale beboere. Selv om kælderen blev betragtet som et sikkert opholdssted, kunne den ikke modstå den fuldtræffer, der ramte, og 36 af de cirka 270 personer, der opholdt sig i sikringsrummene, blev dræbt på stedet, heraf altså 15 danske småbørn og deres to voksne ledere. To børn overlevede mirakuløst, ligesom børnehaven, de havde forladt, slap uskadt fra bombardementet. $^{2}$

Angrebet den 19. maj 1943 var kommet ganske overraskende, for 


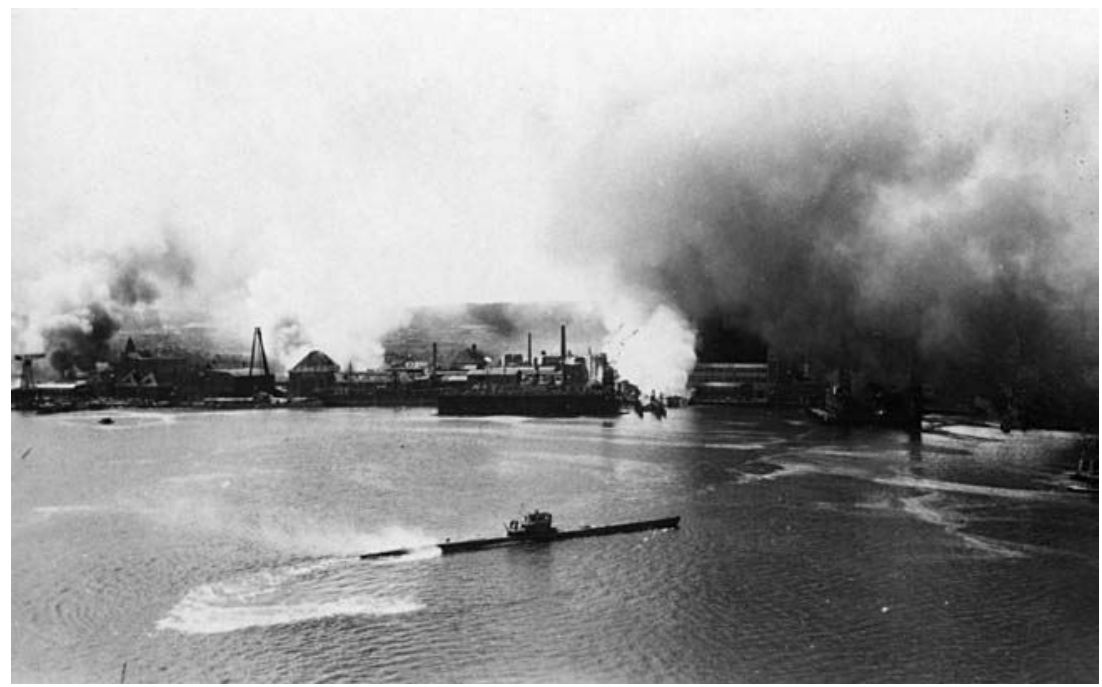

Der eksisterer en del fotos af bombardementet den 19. maj 1943. Dette, der er taget af en ukendt fotograf, har Flensborg havn som motiv og illustrerer, hoor tæe bomberne faldt den skæbnesvangre majdag i 1943. Foto: Arkivet ved Dansk Centralbibliotek for Sydslesvig.

selv om Flensborg var vant til luftalarm, når de allieredes bombefly overfløj byen, så udgjorde den kun sjældent selve bombemålet. Andre byer blev ramt langt hyppigere, og disse mange allierede flyangreb skabte betydelige udfordringer for Joseph Goebbels' propagandaministerium.

Allerede i 1942 sås stigende tegn på social uro, defaitisme og misfornøjelse med styret hos civilbefolkningen, efterhånden som hjemmefronten blev stadigt mere berørt af krigen. ${ }^{3}$ Dette forhold kombineret med omslaget i krigslykken i vinteren 1942/43 - tydeliggjort af det tyske nederlag ved Stalingrad i januar 1943 - tvang Goebbels til at ændre sin propagandastrategi. Hidtil havde de militære sejre været det centrale omdrejningspunkt i propagandaen, men nu blev nøgleordet det tyske folks overlevelse. Herefter blev befolkningen vedholdende bombarderet med et billede af den fortsatte krig som det tyske folks altafgørende overlevelseskamp, der var dem påtvunget af en stadigt mere grusom fjende. ${ }^{4}$ Med sin opfordring til Totaler Krieg kürzester Krieg den 18. februar 1943 gik Goebbels endvidere til modangreb på civilbefolkningens spirende modløshed ved at mobilisere 
også hjemmefronten aktivt i krigen. Således hed det i hans berømte tale i Sportspalast:

"Som det tiende og sidste punkt spørger jeg jer: Ønsker I, sådan som det nationalsocialistiske program kræver det, at de samme rettigheder og de samme pligter - netop her under krigen - gælder for alle, at hjemegnene solidarisk tager krigens tungeste byrder på deres skuldre, og at de bliver fordelt ligeligt på høj og lav, fattig og rig? « ${ }^{5}$

Den nye strategi fik betydning for håndteringen af bombardementerne og deres civile ofre, som ellers havde været lidt af et propagandamæssigt dilemma, lige siden briterne i sommeren 1940 så småt var begyndt at operere i tysk luftrum. Først havde den tyske presse stort set ignoreret angrebene og druknet dem i succeshistorierne om de tyske militære sejre. I oktober 1940 blev pressen således advaret mod at omtale de anrettede skader og pålagt kun at offentliggøre rapporterne fra værnemagtens overkommando. Af frygt for rygtedannelser som et resultat af de manglende reportager beordrede Goebbels imidlertid et år senere - i september 1941 - en mere realistisk behandling af de fjendtlige angreb. Efter de stærkt ødelæggende og tabsgivende angreb på Lübeck og Rostock i april 1942 valgte Goebbels imidlertid igen fortielsen, indtil han i august samme år atter slog om. Nu gav han plads til en omtale af befolkningens heroiske adfærd under de stadig sværere britiske bombardementer, men stadig ikke til omtale af ødelæggelsernes omfang. Befolkningen skulle ikke ynkes, men roses for sin heroisme! Efter at være blevet kritiseret for sin åbenhed strammede han i marts 1943 igen op på mængden af informationer. I overensstemmelse med den nye propagandastrategi instruerede han samtidig pressen om at fokusere på det barbariske i briternes luftangreb for derigennem at forstærke hadet til fjenden og styrke tyskernes indbyrdes solidaritet. Ved at omtale og behandle bombeofrene på samme måde som de faldne frontsoldater blev civilbefolkningens rolle som part i en fælles overlevelseskamp tydeliggjort. ${ }^{6}$ Dette sidste forhold influerede også på begravelserne den 24. maj i Flensborg.

\section{Den tyske begravelsesceremoni}

Propagandaministeriet balancerede til stadighed mellem to behov: På den ene side skulle fjendens bombardementer nedtones, så man und- 
gik at skræmme befolkningen i de ikke-ramte områder, og på den anden side måtte man tilfredsstille de bomberamte befolkningers behov for offentlig anerkendelse af deres lidelser. I begyndelsen af 1943 søgte Goebbels at løse dilemmaet ved på nationalt plan at undgå omtale af størrelsen på fjendens angrebsstyrker og de forrettede skader, men dog tillade lokalpressen i de ramte områder en mere udførlig omtale af angrebene og deres konsekvenser for lokalbefolkningen. Det var imidlertid ikke en ufejlbarlig løsning. I januar 1943 reagerede ofrene for svære bombardementer i Ruhrområdet og Rhinlandet således forbitret på den officielle omtale, fordi den bagatelliserede og anonymiserede angrebene. De bomberamtes vedvarende behov for at få deres ofre kendt og anerkendt af det resterende rige blev håndteret af Goebbels kort efter angrebet på Flensborg, da han introducerede en ny større åbenhed omkring konsekvenserne af de fjendtlige flyangreb. Han håbede dermed at overbevise de ramte befolkningsgrupper om den nazistiske ledelses oprigtige medleven og den øvrige befolkning om fjendens grusomheder. Denne strategi blev imidlertid også snart ændret. ${ }^{7}$

Da bomberne faldt over Flensborg i maj 1943, blev det dog stadigvæk forventet af aviserne, at de kun gengav de officielle kommunikéer, men at lokalpressen i Flensborg ville tilbyde sine læsere en udvidet information om fjendens terrorangreb. Det betyder, at de grundigste beskrivelser af bombardementet og dets følgevirkninger - herunder begravelsen af ofrene - bør skulle findes hos Flensburger Nachrichten og Flensborg Avis. Men det betyder også, at artiklerne i hvert fald i Flensburger Nachrichten må forventes at være ret ensidigt vinklet på propagandatemaerne: fjendens grusomhed og befolkningens stærke indbyrdes solidaritet i nødens stund. Dette udelukker imidlertid ikke, at reportagen fra den tyske begravelsesceremoni har dækket det virkelige forløb ganske præcist. Ofrenes militære begravelse var jo netop iscenesat af de nazistiske myndigheder og derfor - ligesom pressen styret af Goebbels fortælling om det tyske folks solidariske overlevelseskrig mod en grusom fjende.

Den første omtale af bombardementet i Flensburger Nachrichten var da også helt efter bogen kortfattet og formel. I en notits meddelte Reichspropagandaamt Schleswig-Holstein, at angrebet havde fundet sted, og at foreløbig 12 var dræbt og et større antal savnede. ${ }^{8}$ Dagen efter blev tallet - ligeledes i en kort meddelelse - opjusteret til 53 faldne og et større antal let eller svært sårede, ligesom et antal savne- 
de formentlig ville øge det endelige tabstal. ${ }^{9}$ Dødstallet var justeret op til 82 tre dage senere. ${ }^{10}$ Retorikken var som forventet. Den nazistiske kredsleder i Flensborg, Claus Hans, afsluttede en offentliggjort liste med navnene på 64 af de omkomne, herunder de dansksindede, med en politisk erklæring, der - oversat i Flensborg Avis den 24. maj - lød således: »De faldt i den afværgekamp, som Europas folk er tvunget til at føre for deres eksistens mod Vestens med bolshevismen forbundne kapitalistiske stater. Af deres ofre vil det nye Europa opstå. «11

Reportagen fra den tyske begravelse om formiddagen den 24 . maj var langt mere udførlig. Under overskriften »Flensborg tog afsked med sine døde « kunne den tyske avis berette om en nazistisk massebegravelse, hvor kisterne, smykket med hagekorsflag, stod samlet opstillet på kirkegården ved Fredshøjen. Til stede var repræsentanter for værnemagten, partiet, embedsmænd og talrige flensborgere, der »tog del i deres folkefællers tunge skæbne. «12 Talrige kranse blev lagt ved kisterne, hvoraf avisen fremhævede dem fra Gauleiter Lohse, Kreisleiter Hans, repræsentanten for værnemagten og fra byen Flensborg. De sørgende pårørende blev derimod ikke omtalt, og gråd hørtes tilsyneladende ikke. I hvert fald havde marinestationens musikkorps afbrudt »den højtidelige stilhed «, da det indledte ceremonien med tonerne af en sørgemarch. På værnemagtens vegne udtrykte kontreadmiral Ruhfuss dernæst sin medfølelse med flensborgerne og sørgede med dem over tabet af de uskyldige børn, kvinder og mænd, der blev revet bort fra det arbejde, som de trofast udførte for fædrelandet. Deres offer skulle være en påmindelse til alle om at være tro mod Føreren, til sejren var opnået. Derefter talte en repræsentant for luftvåbnet og gav "på afmålt militær maner « en rapport over luftangrebet, der havde kostet angriberne fire bombefly [ifølge senere studier returnerede alle bombeflyene til deres base i England ${ }^{13}$ ]. Kredsleder Hans talte om et skæbnefællesskab, og hvordan angrebet atter havde vist, hvordan alle flensborgere holdt sammen. Skulder ved skulder stod de sammen om at hjælpe hinanden, og dermed havde fjenden opnået det modsatte af det ønskede - i stedet for at svække tyskernes moral, havde de kun forstærket kampviljen. Efter en oplæsning af ofrenes navne, blev fanerne sænket og tre geværsalver afskudt hen over kisterne for at ære de døde. Til tonerne af de tyske nationalmelodier trådte repræsentanter for værnemagten dernæst an og bar kisterne til de opkastede grave, fulgt af de efterladte med Chopins Sørgemarch i ørerne. Her sluttede ceremonien med stille højtideligholdelse, 
trøstende ord og tanker, hvilket var den eneste reference til de pårørendes sorg. Reportagen sluttede med disse opbyggelige ord: »Af disse dødes offer vil det tyske rige, hvortil alle, både front og hjemstavn, har viet deres liv, engang (gen)opstå.«

Som man kunne forvente, blev begravelsen af de tyske ofre udført i fuld overensstemmelse med Goebbels propagandastrategi. Flensborgerne blev ikke ynket, men rost for deres stærke indbyrdes solidaritet og opfordret til fortsat kamp mod fjenden!

Reportagen i Flensborg Avis var fyldigere og havde flere citater fra talerne. Disse bestyrkede dog kun indtrykket af en propagandistisk ceremoni. Danske deltagere i begravelsen har siden suppleret med en omtale af de i propagandaen uvelkomne elementer: religion og sorg. Journalisten Jacob Kronika, der karakteriserede de tyske ofres begravelse som en "statsakt «, ${ }^{14}$ bemærkede således, at tre tyske præster ikke fik adgang til at prædike, fordi talerne var forbeholdt nazisternes politiske repræsentanter. Ifølge Bernhard Hansen, den daværende rektor for Duborg-Skolen og medlem af Folkerådet, heilede en »stab af præster, der åbenbart var privat bestilte « ${ }^{15}$ foran de sorte kister og blev derefter ført bort af en befalingsmand. De blev gemt bag et nærliggende buskads, »til der vel senere blev brug for deres medhjælp. Vi så dem i hvert fald ikke mere «. ${ }^{16}$ Hans oplysninger om pårørende, der »i ikke ringe tal« besvimede og blev båret væk, når der saluteredes over kisterne, viser endvidere, at Flensborg Avis' omtale af »en stor skare af sørgende « ${ }^{17}$ gav et realistisk billede af tyske pårørende, der naturligvis var lige så sorgtyngede, som alle andre ville være i deres situation.

\section{Den danske begravelsesceremoni}

At danskerne begravede deres døde i en egen ceremoni, krævede tysk accept, men herom senere. Her skal det blot konstateres, at Flensborg Avis fik grønt lys til »i hvert fald for så vidt som det drejer sig om vore egne tab - at skrive alt det, der må og skal skrives «. ${ }^{18}$ Ifølge Jacob Kronika, der fungerede som det danske mindretals talsmand i Berlin, hvor han som udenrigskorrespondent havde mange kontakter i ministerierne, kostede det kun en telefonopringning til Goebbelsministeriet. Her udtrykte man sin deltagelse med det danske mindretal og ville ikke blande sig i avisens reportage. "Små gaver bevarer venskabet «, 19 som Goebbels konstaterede i sin dagbog den 3. marts 
1943. Han havde efter et luftangreb på Berlin beredvilligt opfyldt et ønske fra præsten ved den ødelagte Hedwigskirke.

Reportagen i Flensborg Avis kan altså antages at give et dækkende billede af den danske begravelsesceremoni, men også Flensburger Nachrichten udkom med en reportage under overskriften »En gribende sørgehøjtidelighed «. Heri kunne man læse om de 15 dræbte småbørn, der over middag blev begravet sammen med fem voksne ofre på den samme kirkegård, som havde lagt grund til formiddagens tyske begravelse. Præsterne fra den danske menighed havde talt ved kisterne, og den danske rådsherre J.C. Møller nedlagt en krans på vegne af Flensborgs overborgmester. Der blev også overbragt kranse af amtmand Kr. Refslund Thomsen fra Aabenraa på den danske regerings og dermed det danske folks vegne, af legationssekretær Gregers Larsen fra det danske gesandtskab i Berlin og af konsul Ryder fra det danske konsulat i Flensborg. Den danske kammersanger Aksel Schiøtz havde sunget Grundtvigs "Sov sødt, barnlille«, inden rektor Bernhard Hansen fra Duborg-Skolen afsluttede højtideligheden med en varmt følt tale med trøstende ord til de sørgende forældre. Til sidst bar medlemmer af den danske ungdomsorganisation de små kister til graven fulgt af forældrene og andre pårørende. Den tyske avis sluttede i dette tilfælde ikke med en henvisning til det tyske riges fremtid, men med disse medfølende ord: "Flensborgs borgere tager oprigtigt del i den hårde skæbne, der har ramt den danske folkegruppe den 19. maj. $\ll^{20}$

I Flensborg Avis kan man yderligere læse, at Flensborgs drenge- og pigespejdere "paraderede med spejdernes flag, skolens floromvundne banner og Ungdomsforeningens fane $«^{21}$ bag de tyve hvide kister på begravelsespladsen. Disse var smykket med kranse og blomster i stort antal fra ikke kun lokalbefolkningen og mindretallets organisationer syd for grænsen, men også fra en række foreninger og institutioner i Danmark. Tilsvarende bestod det store fremmøde ikke kun af mindretallets egne, men også af »en hel del landsmænd « nord for grænsen. Efter at man havde sunget salmen »lyksalig, lyksalig «, havde mindretallets førstepræst H.P. Petersen bekendt troen og læst nogle skriftsteder; pastor Jordt Jørgensen, hvis distrikt omfattede de ramte familier, forestod prædikenen, og pastor Martin Nørgård foretog de tyve jordpåkastelser, sluttende med et Fadervor. Aksel Schiøtz' sang blev fulgt af de omtalte kransenedlæggelser, suppleret med kranse fra Dansk Samråd og fra Danmarks Børnehaver, repræsenteret ved henholdsvis 


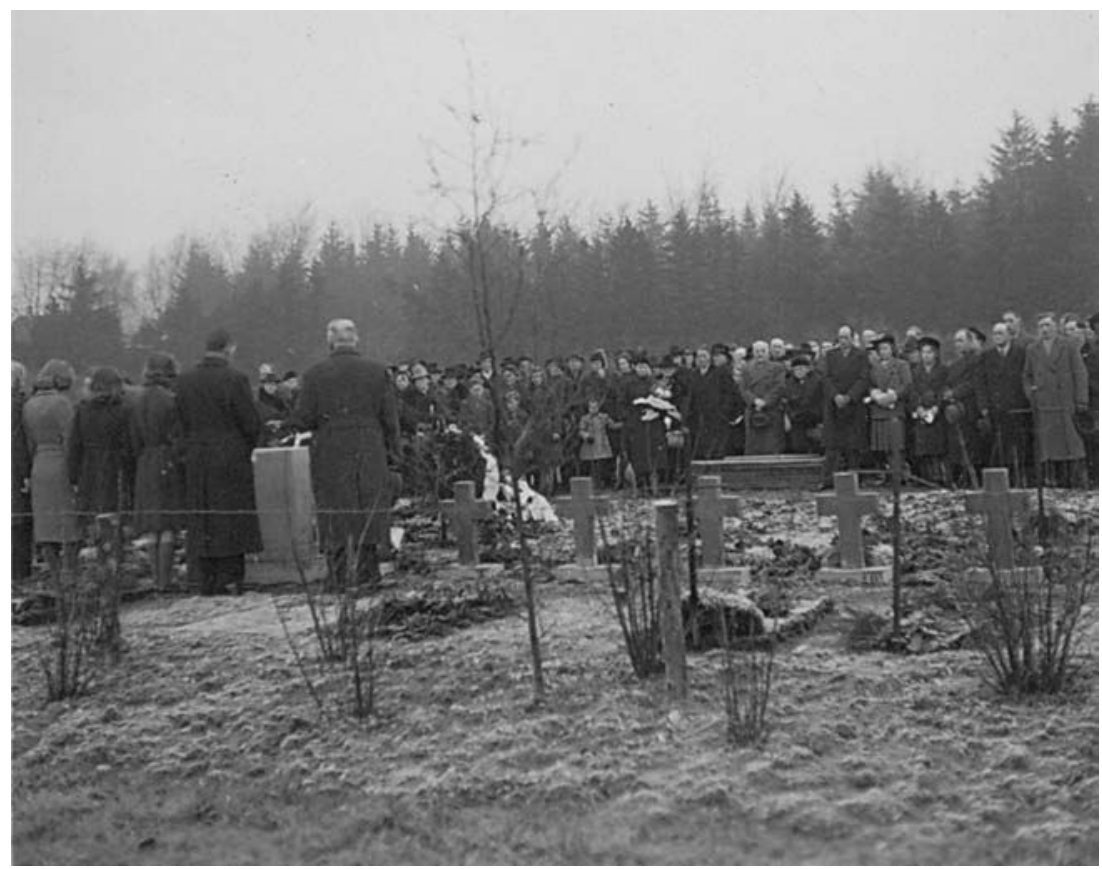

Der findes tilsyneladende ingen fotos fra hverken den danske eller den tyske begravelsesceremoni. Men ovenstående blev taget på kirkegården den 12. december samme år, hvor en mindesten for de omkomne børn blev afsløret. Her lagde pigespejdere blomster på gravene, og Bernhard Hansen (med ryggen til) optrådte som mindretallets officielle taler. Foto: Arkivet ved Dansk Centralbibliotek for Sydslesvig.

Morten Kamphøvener, Aabenraa og Chr. Refslund, Sønderborg. Dernæst fulgte Bernhard Hansens tale over salmen »Så rejse vi til vort fædreland «, 22 hvorefter et vers heraf blev afsunget. Jordt Jørgensen sluttede af med at lyse velsignelsen. Efter at lederen af den ramte børnehave, som ved et tilfælde havde været fraværende på ulykkesdagen, havde ladet blomster lægge på hver enkelt kiste, bar drengespejdere anført af de omtalte faner de 15 barnekister i graven, mens pigespejdere strøede blomster på vejen. Og »Duborg-Skolens floromvundne fane sænkedes over graven under følgets dybe tavshed, kun brudt af de pårørendes gråd. « $^{23}$ Fire af de fem voksenkister jordfæstedes i nærheden af børnegraven, mens den sidste båre blev overført til kirkegården ved Møllegade.

En række andre referater ${ }^{24}$ bekræfter dette forløb, som således må anses for at være en korrekt fremstilling af begivenhederne. 


\section{Præster og nazister - med eller uden?}

Præsternes rolle var en iøjnefaldende forskel på den danske og den tyske begravelsesceremoni. Og det var da også netop ønsket om »en dansk begravelse ved vore egne præster ${ }^{25}$ der ifølge Bernhard Hansen fik ham selv og J.C. Møller, rådsherre i Flensborg og medlem af Folkerådets forretningsudvalg, til hurtigt efter bombardementet at henvende sig til de tyske myndigheder. Den tyske stat, der betalte begravelsesomkostningerne for de faldne, foreskrev nemlig en militær begravelse, og her var der ikke nødvendigvis plads til præster, som det også fremgik af den tyske ceremoni den 24. maj. Der var altså brug for en dispensation.

Det var allerede i mindst to tidligere tilfælde lykkedes at involvere en dansk præst i begravelsen af et dansk krigsoffer. Den 31. oktober 1942 talte pastor Jordt Jørgensen således ved kisten i kapellet, da den 20-årige Anna Petersen blev begravet. Hun var også dræbt ved et flyangreb og havde således officielt givet sit liv for »Fører, Folk og Fædreland $«{ }^{26}$ Ved selve graven tog repræsentanter for nazistpartiet imidlertid over og talte på partiets vegne, hvorefter den nazistiske fanevagt sænkede sine bannere over graven. ${ }^{27}$ Knap et halvt år senere blev en dansk soldat, der var død på et lazaret i Tyskland og derfor kunne hentes hjem til begravelse i Flensborg, ligeledes jordfæstet under Jordt Jørgensens medvirken, dog uden tilladelse til salmesang. Præstens rolle var egentlig reserveret den tyske marinepræst fra Mørvig, men med besvær fik familien altså en dispensation. De slap dog ikke for et nazistisk æreskompagni, der først stod vagt i kapellet og siden affyrede en æressalve ved graven, eller for at få kisten dækket med et hagekorsflag. ${ }^{28}$

Det aktuelle ønske om danske præsters medvirken ved begravelsen af ofrene fra den 19. maj gik heller ikke glat igennem. Ifølge Bernhard Hansen blev det tværtimod mødt med »foragt og højrøstede hånsord «. ${ }^{29}$ En sådan modvilje mod de danske præsters deltagelse i begravelsen vil kunne forklares med nazisternes generelle prioritering af partiet over kirken, men det er muligvis ikke den eneste forklaring. Således hed det i en tysk indberetning til regeringspræsidenten i Slesvig fra oktober 1943, at den danske grænsebefolkning arbejdede tæt sammen med præsterne, der var meget mere end bare sjælesørgere for den danske bevægelse: »De danske præster opfylder en politisk mission. «30 Præsterne skulle især have stærk indflydelse på skolespørgsmål og søgningen til børnehaverne. 
Ernst Schröder, der havde forfattet indberetningen, var ikke en hr. hvem som helst. Han var den centrale leder af det decentrale Grenzgürtelarbeit, der siden 1936 havde haft til formål at styrke tyskheden i grænselandet og bremse de dansksindedes påståede kulturelle fremstød i Sydslesvig. Dette tysknationale arbejde, der i betydeligt omfang udartede sig til en regulær forfølgelse af det danske mindretal, blev uofficielt finansieret af nazistpartiet, som Ernst Schröder således havde et tæt samarbejde med. Såfremt de lokale partifunktionærer delte hans syn på de danske præster, vil det også kunne forklare en mulig modvilje mod at lade præsterne begrave Flensborgs danske krigsofre. Men var Ernst Schröders opfattelse af de danske præsters politiske funktion rimelig? Tja, præsterne havde en bred kontakt til mindretallets medlemmer og blev alene af den grund - frivilligt eller ufrivilligt - centrale aktører i mindretalsarbejdet. De to præster, Jordt Jørgensen og H.F. Petersen, giver i deres trykte erindringer da også udtryk for et stærkt personligt engagement i mindretallet, og H.F. Petersen var aktivt medlem af Folkerådet i maj 1943, hvor begravelsesceremonien blev planlagt. Det er således forståeligt, at Ernst Schröder så dem som ikke kun sjælesørgere.

Den aktuelle modstand blev imidlertid overvundet, og de danske præster forestod begravelsen af de danske ofre, denne gang endda uden at være sekunderet af nazister som ved de to tidligere begravelser. Dette fravær af nazistiske aktører var en anden væsentlig forskel i forhold til den tyske ceremoni, men hvorfor insisterede nazisterne ikke på at være til stede ved den danske begravelse?

Ifølge den danske konsul i Flensborg havde J.C. Møller allerede den 20. maj kontaktet Flensborgs overborgmester Kracht. Her havde han fremlagt mindretallets ønske om at begrave de danske ofre »under hensyntagen til dansk skik og de pårørendes ønsker «. ${ }^{31}$ Kracht havde intet at indvende, men henviste til nazistpartiet, der også skulle give sin godkendelse. Møller opsøgte derfor den nazistiske kredsledelse næste dags formiddag, ledsaget af Bernhard Hansen, der ifølge L.P. Christensen, redaktøren for Flensborg Avis, trak det tunge læs i forberedelserne af begravelsen. ${ }^{32}$ Disse forhandlinger kaldte Bernhard Hansen siden »mistrøstige og ydmygende «33 og »et nedslående drama «, ${ }^{34}$ for de nazistiske partifolk ville have ofrene begravet efter det militære ritual og var især oprørte over ønsket om præsternes deltagelse. Bernhard Hansen har fortalt, at det var Kronika, der i Berlin klarede paragrafferne, så tilladelsen næste aften alligevel kom i hus. ${ }^{35}$ 


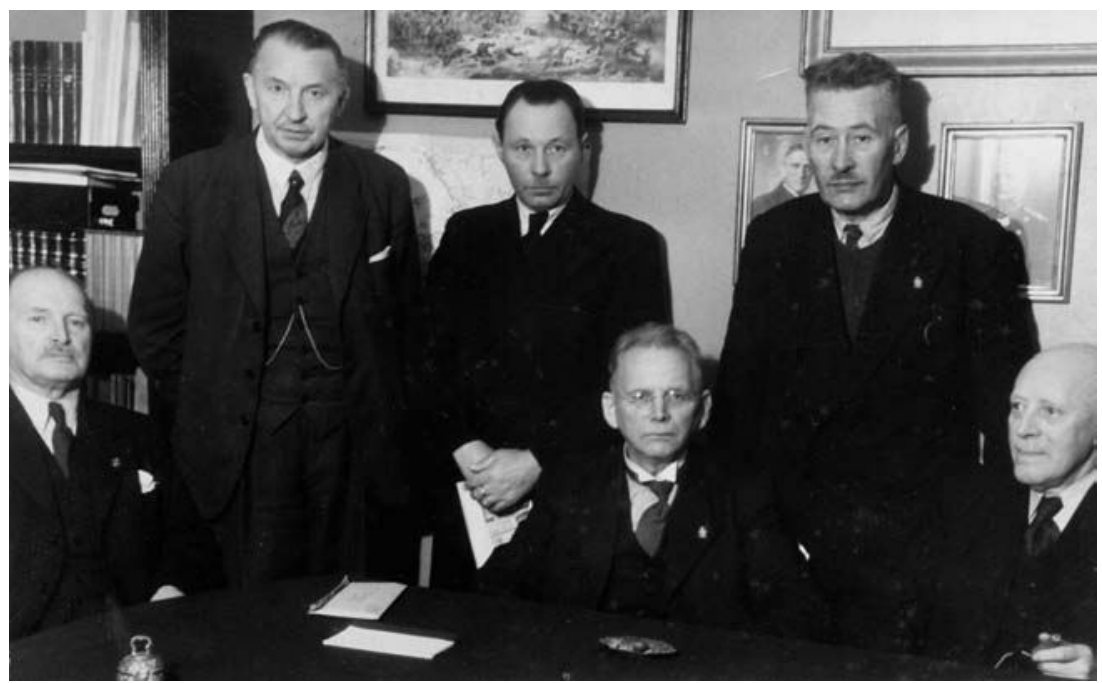

Bernhard Hansen var ikke kun en central person i tilrettelæggelsen af begravelsesceremonien. Efter verdenskrigen deltog han flere gange $i$ de delegationer, der forhandlede med den danske regering om de sydslesvigske spørgsmål. Således også her i november 1945, hoor han ses bagest i midten. Foran ham sidder den også omtalte L.P. Christensen. Foto: Arkivet ved Dansk Centralbibliotek for Sydslesvig.

Kronika har dog intet nævnt herom, men derimod kun at han hjalp avisen til at kunne rapportere frit. ${ }^{36}$

Konsul Ryders ret detaljerede beskrivelse af forhandlingsforløbet nævner heller ikke Kronika - eller for den sags skyld, at der skulle have været tale om stærk lokal modstand mod de danske begravelsesplaner. Han skriver blot, at kredsledelsen ønskede at forelægge spørgsmålet for de højere partimyndigheder, hvorfra der samme aften kom et svar, »som fuldstændigt godkendte de danske ønsker «. ${ }^{37}$ Hans indberetning slutter med at konstatere, at de »herværende myndigheder [...] såvel i ord som i gerning har udvist den største forståelse for den dybe sorg, som har ramt mindretallet, og for dettes ønsker om, at begravelsen - med deltagelse også nordfra - kunne forme sig efter ren dansk skik«. Andre kilder, der har omtalt forhandlingerne, men uden selv at have været til stede, bringer ikke mere klarhed over den nazistiske kredsledelses holdning til de danske ønsker. Hans Futtrup, lærer på Duborg-Skolen, har gentaget Bernhard Hansens udlægning, ${ }^{38}$ mens redaktør L.P. Christensen, der også befandt sig i Folkerådets inderkreds, kun omtaler gentagne forhandlinger med »over- 
borgmesteren, politiledelsen osv., der siden henvendte sig til højere steder « ${ }^{39}$ Her fandt mindretallet forståelse for, at de danskes jordfæstelse skulle frigøres fra den officielle tyske ceremoni. Det kan altså ikke afgøres, i hvilken grad de lokale nazister har skullet »sættes på plads« af den politiske ledelse i Berlin. Det forekommer til gengæld ret indlysende, at Berlin har fundet det uklogt at fremture mod mindretallet i en situation, hvor det havde Danmarks fulde bevågenhed (det var i så fald hverken første eller sidste gang, at udenrigspolitiske hensyn beskyttede mindretallet mod oplevede overgreb fra den lokale flertalsledelse). Og da tilladelsen til en begravelse »efter ren dansk skik « først var givet, var det vel en logisk konsekvens, at begravelsen undgik nazistiske indslag, og at overborgmester Kracht på selve dagen overlod det til J.C. Møller at nedlægge bystyrets krans.

\section{En fælles begravelsesceremoni - et fællestræk}

Der var ikke kun forskelle mellem de to begravelser, men også ligheder. Således var der i begge tilfælde tale om en fællesbegravelse med deltagelse af uniformerede fanevagter og med taler af verdslige repræsentanter for de to samfunds øverste ledelse. Men kunne det så kaldes en begravelse »efter ren dansk skik «?

En dansk tradition for store fællesbegravelser kan i hvert fald ikke påvises. Nu har anledningerne heldigvis heller ikke været så mange. En del ulykker med mange danske dødsofre er sket i forbindelse med kollektive transportmidler, hvor ofrene har været på rejse. De er efterfølgende blevet ført til deres respektive hjemsogne og begravet der. Det gjaldt for eksempel ved de store togulykker ved Bramming i 1913 og Villerslev i 1919 og skibsulykken på Haderslev Dam i 1959. 12 ofre for en eksplosionsulykke på Århus Havn i juli 1944 blev derimod begravet $i$ en fællesgrav efter en højtidelighed i Domkirken, men det var kun, fordi de ikke kunne identificeres - de øvrige 20 omkomne blev begravet individuelt. Heller ikke de 18 århusianske ofre for flyangrebet på Gestapos hovedkontor i Århus samme år blev begravet ved en fællesceremoni. Eksplosionen på Holmen i 1951 med 16 omkomne affødte til gengæld en fælles begravelsesceremoni for de 14 dræbte brandfolk og Falckreddere. ${ }^{40}$ På tilsvarende måde blev otte nonner fra Den Franske Skole, der blev ødelagt under det britiske luftangreb på Shellhuset i København marts 1945, begravet ved en fællesceremoni og kisterne nedsat side om side. Men de 86 skolebørn, 
der omkom ved samme lejlighed, blev begravet enkeltvis af forældrene. Dog afholdt den katolske kirke en fælles mindegudstjeneste med deltagelse af en lang række offentlige repræsentanter. ${ }^{41}$

I maj 1943 var der altså ikke nogen dansk tradition at læne sig op ad, da det danske mindretal begravede de 20 ofre ved en fælles offentlig ceremoni, så hvorfor valgte mindretallet denne løsning? Der har næppe været tale om et krav fra de tyske myndigheder, for ifølge konsul Ryder var programmet lagt af den danske mindretalsledelse allerede inden det første møde med den nazistiske kredsledelse. ${ }^{42}$ I øvrigt var det kun 48 af de 58 tyske ofre, der indgik i tyskernes fælles ceremoni, ${ }^{43}$ så ikke engang her var der tale om et ufravigeligt krav, ligesom det jo heller ikke var det for de fire danske ofre, der blev begravet individuelt. Da den tyske stat betalte begravelsesomkostningerne for de bombedræbte, ${ }^{44}$ har den danske fællesbegravelse næppe heller været tænkt som en nødvendig begravelseshjælp til de ramte forældre, selv om flertallet vitterligt var økonomisk trængte. Ni af de 15 dræbte småbørn kom således fra i alt syv familier, der befandt sig i en egentlig trangssituation og derfor modtog et fast månedligt beløb fra Dansk Menighedsplejes forældrehjælp. ${ }^{45}$ Derimod kan det have været et argument, at man har villet aflaste de sorgramte og chokerede mødre, der i de tilfælde, hvor fædrene var indkaldt, stod alene med tragedien. Men i så fald kunne mindretalsledelsen jo også have tilbudt at arrangere enkeltbegravelser, der måske ville have været en mere skånsom løsning for forældrene, hvoraf fire par havde mistet to børn og et par deres eneste barn. Kilderne røber intet om disse overvejelser, men Bernhard Hansen stillede sig selv et lignende spørgsmål, da han senere på sommeren skulle besøge de ramte mødre på deres fælles rekreationsophold på Als Husholdningsskole: »Sorgen havde været hård at brydes med, og om der er trøst i fælles sorg i et tilfælde som dette, er vel ikke let at sige, måske var byrden i stedet blevet dobbelt tung. «46 Den samme tvivl må også have naget, da begravelsesplanen blev udarbejdet i timerne mellem besøget hos overborgmester Kracht den 20. maj og besøget hos kredsledelsen den næste dags formiddag. Et andet nærliggende spørgsmål er, om de ramte forældre blev taget med på råd, og om de overhovedet så kort efter tragedien selv var i stand til at overskue spørgsmålet om begravelsesformen.

De fire omkomne danske, der ikke indgik i den fælles danske ceremoni, var ifølge Flensborg Avis »forinden af særlige grunde i stilhed 
[...] stedt til hvile på en af byens ældre kirkegårde «. ${ }^{47}$ At de skulle gravsættes på en anden kirkegård, var dog ikke i sig selv en grund til at fravælge den fælles ceremoni - således var den 85-årige Christine Paulsens båre at finde blandt de 20 på Fredshøjen, selv om den efterfølgende skulle gravsættes på kirkegården ved Møllegade. Det må altså især have været behovet for en stille privat begravelse, der afgjorde valget, hvilket med sikkerhed var tilfældet for familien til den 45-årige fransklærerinde ved Duborg-Skolen Eli Jessen, gift med redaktør Tage Jessen ved Flensborg Avis. Hun blev begravet »i stilhed til stor sorg for mange, da hun var meget afholdt « ${ }^{48}$

\section{De verdslige fællestræk}

Den tyske begravelse var en officiel, verdslig ceremoni, men også i den danske begravelse sås lignende ikke-religiøse elementer. Ligesom kredsleder Claus Hans afsluttede den tyske ceremoni som repræsentant for Flensborgs nazistiske topledelse, således optrådte rektor Bernhard Hansen som repræsentant for mindretallets centralledelse, da han holdt den afsluttende tale i den danske ceremoni. Det fremgår ganske vist ikke af Flensborg Avis på hvis vegne, Bernhard Hansen talte, og kilderne er ikke entydige. Skoleforeningens beretning for skoleåret 1942/43 oplyser, at skolekonsulenten [Bernhard Hansen] bragte "skolevæsenets hilsen «, 49 og selv skrev han i 1968, at »skolens farvel « ${ }^{50}$ blev sagt på Fredshøjen, fordi man ikke turde indbyde til et afsluttende samvær på Duborg-Skolen. Man undgik i det hele taget større sammenkomster af frygt for de daglige overflyvninger. I hans erindringer fra 1971 hedder det derimod blot, at »som skolens rektor måtte [han] så på alles vegne tolke det sidste farvel «. ${ }^{51}$ Det har dog næppe gjort den store forskel for de tilstedeværende på Fredshøjen den 24. maj, om Bernhard Hansen optrådte på mindretallets vegne i sin egenskab af medlem af Folkerådets forretningsudvalg, som rektor for Duborg-Skolen eller som konsulent for Skoleforeningen, hvorunder børnehaverne sorterede.

Der er formentlig heller ingen, der har tænkt nærmere over, at det var spejdere, der paraderede med flag ved kisterne, (selv om ingen af de dræbte var spejdere), og dermed udgjorde en pendant til de nazistiske organisationers fanevagt ved den tyske begravelse. Siden oprettelsen af den første spejdertrop i 1919 havde Flensborgs spejdere nemlig tilbagevendende optrådt i forreste geled ved større mindre- 


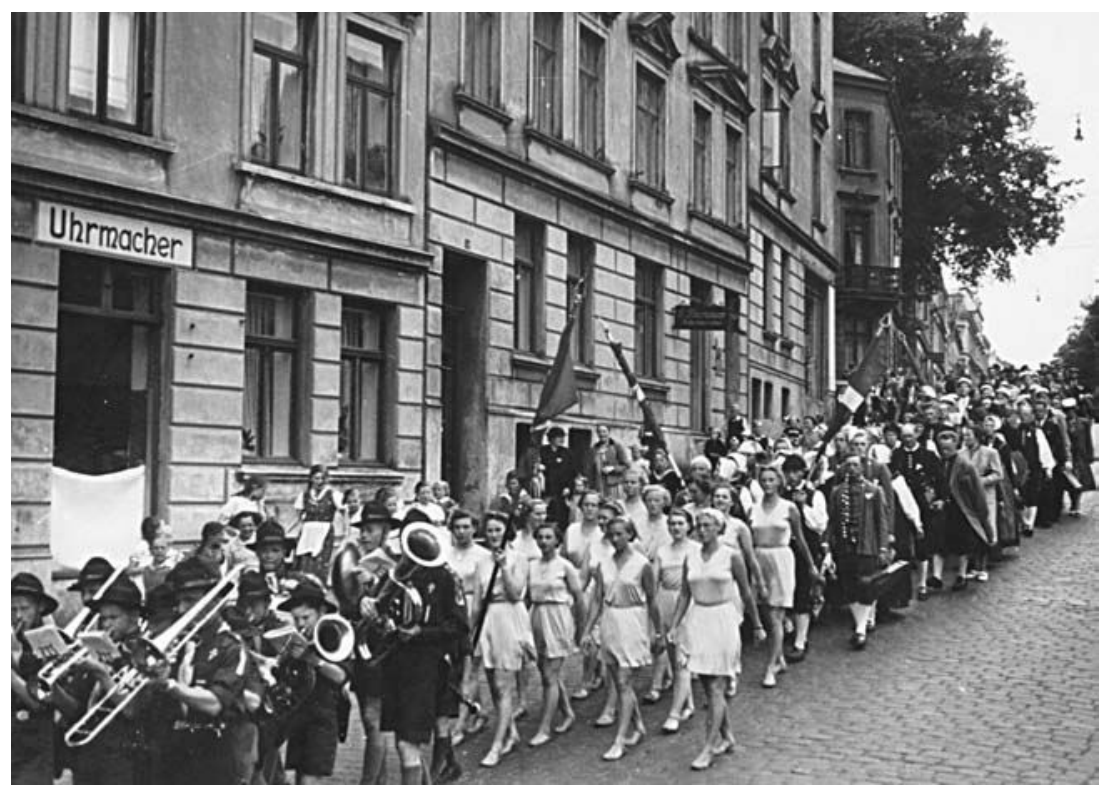

Det danske mindretals årsmødeoptog 11. juni 1939. I spidsen ses spejderorkestret $i$ fuld uniform. Da mindretallets drenge og piger var fritaget for at deltage i Hitlerjugend, kunne de $i$ stedet engagere sig $i$ det danske spejderarbejde, som $i$ Sydslesvig havde et stærkt nationalt præg. Foto: Arkivet ved Dansk Centralbibliotek for Sydslesvig.

talsarrangementer som for eksempel de årlige årsmøder. ${ }^{52}$ At de i 1943 stadig kunne optræde offentligt - oven i købet i fuld uniform skyldtes det forhold, at de danske foreninger havde overlevet nazisternes Gleichschaltung [ensretning], og at spejderne ikke var blevet forbudt at bære deres uniform. Ifølge spejderen Gerhard Ernst var det en "gavmildhed «, som de "gjorde rigelig brug af «, selv om en sådan åbenlys demonstration af dansk sindelag udløste mange korporlige overfald, begået af jævnaldrende medlemmer af Hitler Jugend. ${ }^{53}$

Det var derimod mere bemærkelsesværdigt, at det også var 13-15årige drengespejdere, der var udset til at bære de danske barnekister i graven - en funktion, der ved den tyske ceremoni blev udført af delegerede fra værnemagten. For de store drenge og vel også for de pigespejdere, der havde til opgave at strø blomster på vejen, blev det en svær opgave. De måtte ad tre-fire omgange - fordi de kun var nok til at bære fire kister ad gangen - bære kisterne den lange vej fra begravelsespladsen ned i fællesgraven, »mens enkelte mødre hagede 
sig fast «. ${ }^{54} »$ Et forfærdeligt minde « ifølge den dengang 13-årige Harald Duggen. ${ }^{55}$ Korpschefen Hans Futtrup blev tilsyneladende også betænkelig, da han så, hvordan drengene græd, hver gang de måtte tilbage for at bære fire nye kister. ${ }^{56}$ Én af disse har således fortalt, at Futtrup kontaktede dem for at høre, om de nu også kunne klare det, dengang de skulle bære for fjerde gang. ${ }^{57}$

Det var Bernhard Hansen, L.P. Christensen og I.C. Møller fra Folkerådet, der havde bedt Futtrup om spejdernes hjælp, men siden satte han selv spørgsmålstegn ved det rigtige i denne disposition. »Hvordan havde man reageret i dag? «, spurgte han og gav selv svaret: »Nej, ikke børn! «58 Bernhard Hansen har derimod affejet enhver tvivl om det rigtige i »denne særprægede spejderopgave«, som han kaldte den, for »Drengene bad selv om det. Det ville de «. ${ }^{59}$ Frivilligheden kan imidlertid diskuteres. Ifølge Futtrup havde én af spejderne ganske vist svaret, at børnehavebørnene ikke skulle bæres "af nogen andre, og i hvert fald ikke af nazisterne «, 60 dengang de blev spurgt. I samme retning har en af de ældste kistebærere, den dengang 15-årige Karl Otto Meyer, begrundet spejdernes medvirken: De mange indkaldte mænd gjorde det svært at skaffe voksne bærere nok, og det var uantageligt at anvende byens officielle ligbærere, da der så ville blive heilet ved graven. ${ }^{61}$ Spejderne bar imidlertid ikke de fire voksenkister, der blev gravsat i nærheden af småbørnenes grav, så for disses vedkommende må der have været pårørende og naboer nok til at bære. Desværre oplyses der intet herom i kilderne, ligesom ingen af de interviewede, der dengang var til stede, erindrer denne del af begravelsen. Spørgsmålet er imidlertid, om man kan tale om et frit valg, hvis drengene traf det på forkerte eller ufuldstændige præmisser, eller hvis de ikke kunne overskue, hvad opgaven indebar? Søren Andresen, dengang 14-årig bærer, har i 2010 berettet, hvordan tragedien først for alvor gik op for ham, da han så rækken af kister på kirkegården, hvor »indtrykkene var så voldsomme, at de både lammede mig og ophævede sig selv indbyrdes. Min fatteevne slog simpelthen ikke til.$^{62}$ Et andet forhold relativerer frivilligheden i drengenes tilsagn: De var så tæt knyttet til Hans Futtrup, som også var deres lærer på Duborg-Skolen, at det nære og tillidsfulde forhold måtte gøre det meget svært at sige fra. I hvert fald sagde ingen nej, da han spurgte dem. ${ }^{63}$ Man bør heller ikke se bort fra ånden i spejderloven, der krævede, at en spejder var »nyttig og hjælpsom mod alle«, »en god kammerat!«, »lydig« og »frejdig «, ${ }^{64}$ hvilket - kombineret med traditionen 
for at deltage i mindretallets store arrangementer - har gjort det mere nærliggende for spejderne at sige ja end nej til opgaven.

\section{En samlet vurdering}

Der er ingen tvivl om, at tabet af de 24 udløste en dyb sorg i det danske mindretal, og at ikke mindst de 15 småbørns død blev oplevet som aldeles ubærligt. Ernst Schröder - danskernes onde ånd qua sit Grenzgürtelarbeit - skrev således godt fire måneder senere i en indberetning til regeringspræsidenten i Slesvig: »Det danske mindretal syd for grænsen har oplevet sit største følelsesmæssige chok, da 25 [sic] børn fra en dansk børnehave omkom ved angrebet på Flensborg." Og han tilføjede: »Begravelsen var værdig og stort anlagt [in grossen Rahmen]. ${ }^{65}$ En anden tysk kilde, Flensburger Nachrichten, kaldte den danske ceremoni "gribende«, mens Flensborg Avis i sin reportage vurderede, at »Det blev en højtidsstund, som deltagerne sent vil glemme ${ }^{66}{ }^{6}$ Aviserne lå dermed på linje med en række udsagn fra andre deltagere. ${ }^{67}$

Den danske begravelsesceremoni blev imidlertid andet og mere end en sørgehøjtidelighed. Den blev i sin »stort anlagte« form også en national manifestation, der viste, at det danske mindretal nok var svækket, men ikke knækket. For svækket var det i maj 1943 efter ti år under nazistisk styre. Medlemstallet i Slesvigsk Forening i Flensborg var i tiåret 1932-1942 faldet fra 3.663 til 1.942 og altså næsten halveret. ${ }^{68}$ Aktiviteterne i de forskellige distrikter var vigende, og de sidste tre år var mindretallets årlige festdag, årsmødet, reduceret fra det sædvanlige store friluftsarrangement til et mindre indendørs møde i Flensborghus. ${ }^{69}$

Fremtiden så heller ikke lovende ud. Stadigt flere af mindretallets unge mænd faldt på slagmarken og gik for evigt tabt for mindretalsarbejdet. Elevtallet i de danske skoler havde været konstant faldende siden 1936, hvor det toppede med 967 elever, og i 1943 var det mere end halveret. ${ }^{70} \mathrm{Og}$ nu havde man yderligere mistet 15 af de allermindste »kostelige små led, som vi nærede forhåbninger til, og som vi så nødigt ville miste «, ${ }^{71}$ som børnehavebørnene blev omtalt i Flensborg Avis. Den nazistiske virkelighed var indiskutabelt hård ved det danske mindretal. Ganske vist havde det formelt bevaret retten til sit eget kulturelle liv og havde dermed kunnet opretholde sine egne foreninger og sit eget skolevæsen, men reelt set havde dets medlem- 
mer svært ved at fungere i det ensrettede Tyskland, fordi de stod uden for det nazistiske folkefællesskab. Det lykkedes da også nazisterne at presse et betydeligt antal dansksindede ud af mindretallets foreninger og få dem til at flytte deres børn fra dansk til tysk skole ved at true dem på deres arbejde, understøttelse, børnebidrag m.m.

Mindretallet havde altså grund nok til pessimisme i foråret 1943, men alligevel var der optimisme at spore. I hvert fald noterede Ernst Schröder i en indberetning en måned før det katastrofale flyangreb, at der i det danske mindretal var dukket et vist vovemod op »i ord og fagter « efter det tyske nederlag ved Stalingrad, og at medlemmer af mindretallet nu forudsagde krigens endeligt og Tysklands undergang. ${ }^{72}$ Dette spores også i Folkerådets protokol. Den 1. februar 1943 gjorde man sig overvejelser om, hvilke krav der skulle stilles efter krigen, men besluttede dog samtidig at minde de menige medlemmer »om at være forsigtig i deres udtalelser og afholde sig fra at drøfte fremtidsspørgsmål «. ${ }^{73}$ Den 8 . marts blev det diskuteret, hvordan der kunne skaffes nye medlemmer til Slesvigsk Forening, og redaktør Tage Jensen vandt tilslutning til et forslag om afholdelse af fem store møder, inklusive årsmødet og den danske konges fødselsdag. På mødet den 5. april blev årsmødet planlagt til den 6. juni med spejderparade på Duborg-Skolen og efterfølgende møde i Flensborghus, altså igen kun et indendørs årsmøde. Det Folkeråd, der en måned senere måtte forholde sig til tragedien den 19. maj, vejrede således morgenluft og havde indledt bestræbelser på at samle alle dansksindede og styrke den Slesvigske Forening, selv om det stadig valgte at træde forsigtigt i forhold til de nazistiske omgivelser.

Kilderne fortæller ikke, hvilke overvejelser ledelsen gjorde sig om begravelsen af de danske ofre, altså bortset fra at det skulle foregå efter dansk skik med deltagelse af de danske præster. Hvorfor det endte som en »stort anlagt« fælles begravelsesceremoni med tydelige nationale indslag, ved vi derfor ikke. Vi kan heller ikke vide, om hensigten udelukkende var at vise de pårørende, at der stod en samlet dansk folkegruppe bag dem, eller om Bernhard Hansen og hans kolleger i Folkerådet også øjnede muligheden for at vise omgivelserne, hvor levende og aktivt mindretallet trods alt stadig var. Kun kan vi konstatere, at mindretallet den dag på Fredshøjen fik demonstreret sin eksistens, sin danskhed og sit sammenhold på en måde, der gjorde et stærkt indtryk ikke blot på dets egne fremmødte medlemmer, men også på Flensborgs tyske presse og på rigsdanskerne i Danmark. Ar- 
rangementet blev altså rigtig god propaganda for mindretallet, som dermed fik et tiltrængt løft midt i al sorgen. Om dette resultat skal rubriceres blandt lighederne eller forskellene i forhold til den tyske ceremoni, må overlades til læsernes subjektive afgørelse.

At der virkelig var tale om en national dansk manifestation, fremgår ikke kun af deltagelsen af de officielle repræsentanter fra Danmark, af den verdslige mindretalsleder Bernhard Hansens rolle som taler, af den danske kammersanger Aksel Schiøtz' optræden, af spejdernes fanevagt og funktion som kistebærere, af fraværet af Flensborgs tyske repræsentanter eller for den sags skyld af de mange kranse, der havde ribbet markedet for rød-hvide kransebånd. ${ }^{74}$ Det fremgår også af nogle af reaktionerne på ceremonien. Jordt Jørgensen kaldte direkte begravelsen for »en smuk og værdig dansk tilkendegivelse «, ${ }^{75}$ og legationssekretær Gregers Larsen fandt, at »Den danske sørgehøjtidelighed var meget gribende og helt igennem dansk «. ${ }^{76}$ Bernhard Hansen syntes selv, at højdepunktet var Axel Schiøtz' sang, altså når han så bort fra, »da danske drenge i Duborg-Skolens blå-gule spejderuniformer i sluttet række bar de 15 hvide barnekister bort til de åbne grave «. ${ }^{77} \mathrm{Og}$ her skal endnu en gang gøres opmærksom på den særlige rolle, spejderne havde som mindretallets nationale bannerførere. Således havde Hans Futtrups forgænger som korpschef, Svend Johannsen, i 1937 opfordret til et liv som spejder som en måde at styrke danskheden på. Det skulle blandt andet ske ved hver dag at vise de danske farver i byens gader, fordi »Danskheden i Sydslesvig vil vinde mod og tillid, når den ser, at den danske ungdom har mod og selvtillid «. ${ }^{78}$ Det var i øvrigt ikke kun de spejdere, der var udset til at bære kister og strø blomster langs vejen, der bidrog til den nationale demonstration. Alle børn, der var spejdere, var bedt om at møde op i uniform til begravelsesceremonien. 13-årige Anni Hüpfel, der var én af dem, fandt, at »som altid var vi trods sorg stolte over at kunne gå i spejderuniform ${ } .{ }^{79}$

Der sås også nationale referencer i mange af de sympatitilkendegivelser, der blev sendt til Flensborg Avis fra Danmark. Der blev talt om »folkefæller « og »landsmænd «, og mindretallet kvitterede for »den varme følelse af fællesskab, der i disse dage har fundet så smukt et udtryk fra vort moderlands side, lige fra Kristiansborg og ud i befolkningens brede lag «. ${ }^{80} \mathrm{I}$ flere af hilsnerne blev det fremhævet, at de dræbte børn var vigtige brikker i mindretallets fremtid. »Det var jo jer, vi satte vor lid til«, skrev en forhenværende lærerinde fra Kol- 


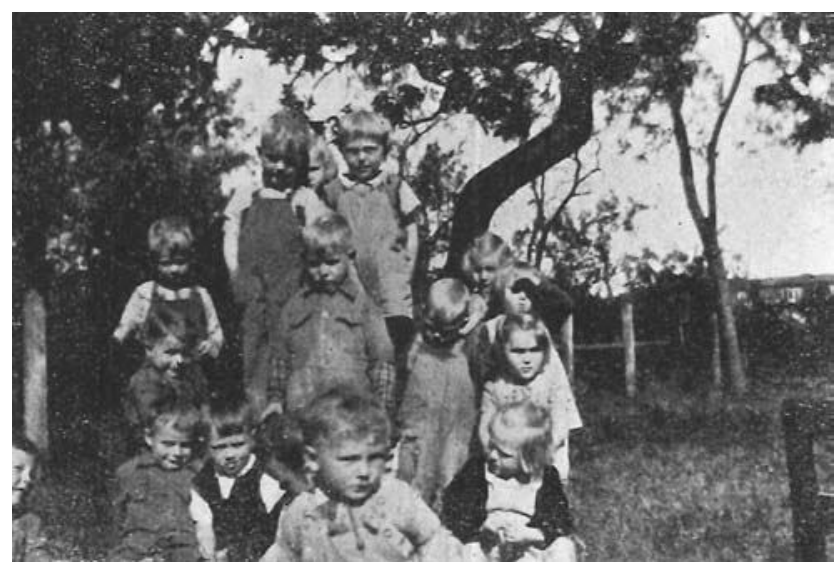

Den 19. maj 1943 var Ingridhjemmets leder fraværende. Den unge medhjælper, Wanda Radszewski, havde derfor taget sin mor med $i$ børnehaven, så de kunne være to til at håndtere en eventuel luftalarm. Måske var det moderens tilstedeværelse, der fik Martha til at medbringe et kamera og helt ekstraordinært fotografere børnene den fatale dag. Filmen blev bagefter fremkaldt og kunne således levere dette sidste minde om de dræbte børn. Dansk Skoleforening Flensborg, Årsberetning nr. 21, 1942/43, s. 70 .

ding, ${ }^{81}$ mens rektor Buchreitz fra Aabenraa Statsskole i en mindehøjtidelighed på skolen blandt andet sagde: »De små ofre var jeres kammerater, et lille led i det danske folk, deres forældres fremtidshåb og vort fremtidshåb. ${ }^{82}$ Kaj Munk var inde på det samme, da han i Berlingske Tidende begræd de »15 gode danskes manddomsgerning, der skal undværes engang «. 83

Rigsdanskernes solidaritet med mindretallet kom også til udtryk i praktiske handlinger. For eksempel flagede sønderjyderne - på opfordring af Dansk Samråd - på halv stang samtidigt med ceremonien i Flensborg, ${ }^{84}$ og mange lokale Sønderjyske Foreninger foretog en pengeindsamling, resulterende i godt 63.000 kr.. Da det var et større beløb, end de bomberamte familier havde brug for, kunne Folkerådet lægge til side til eventuelle nye nødsituationer. ${ }^{85}$

\section{Konklusion}

Bombardementet den 19. maj 1943 udløste ikke kun ubærlig sorg hos de dræbtes pårørende, men rystede hele det danske mindretal. »Alle danske, som på nogen måde kunne være til stede ${ }^{86}$ deltog derfor i 
den fælles begravelse fem dage senere på Fredshøjen. Det var en stort anlagt ceremoni, der samstemmende blev betegnet som en gribende højtidelighed. Den blev både omtalt i Flensborgs tyske avis og i den danske presse og udløste oprigtig medfølelse med ikke kun de pårørende, men hele det danske mindretal. De dræbte, hvoraf de 15 småbørn i særlig grad kaldte på fortvivlelse, blev således ikke kun set som krigens uskyldige ofre, men som krigens uskyldige danske ofre. Deres tilhørsforhold til mindretallet var forudsætningen for, at de overhovedet blev begravet ved en særskilt dansk ceremoni, og danskheden blev markeret både ved iscenesættelsen af ceremonien og med italesættelsen af tragedien.

Kilderne fortæller ikke om de overvejelser og bevæggrunde, der lå bag ceremonien, men som det gik, blev begravelsen mere end en religiøs handling. Den blev også en tiltrængt offentlig manifestation af et levende dansk mindretal, der stod sammen skulder ved skulder. Det var et vigtigt signal at sende til mindretallets egne medlemmer, der levede under et stærkt pres fra de nazistiske omgivelser og i betydeligt antal havde følt sig tvunget til at forlade den Slesvigske Forening og opgive de danske skoler. Budskabet om dansk sammenhold nåede samtidigt de lokale nazister, der hidtil med tilfredshed havde solet sig i den faldende tilslutning til mindretallets institutioner, og det nåede det Danmark, uden hvis støtte mindretallet var ilde stedt.

Efter begravelsen den 24. maj valgte mindretalsledelsen at aflyse det nært forestående årsmøde. Selve begravelsen havde imidlertid de tragiske omstændigheder til trods - givet mindretallet en intens oplevelse af fællesskab, der - i kombination med det spirende håb om et kommende tysk sammenbrud - måtte virke inspirerende på det fortsatte arbejde.

Sammenhold og fremtidstro var netop de værdier, som Goebbels med sine propagandaforskrifter søgte at fremmane i den tyske befolkning. Hans propagandastrategi lagde rammerne for den nazistiske begravelse af de tyske ofre, og talerne angreb således de allierede fjender, men roste flensborgerne for deres solidariske optræden og opfordrede til fortsat modstand. Modsat den danske ceremoni, hvor hovedvægten var lagt på den religiøse del, var præsterne her kun statister, og talerne blev leveret af lokale nazistiske ledere og militærpersoner. Om det så vitterligt lykkedes dem at indgyde Flensborgs civilbefolkning det ønskede mod - eller om de misundeligt har skelet til det danske mindretal - er et helt andet spørgsmål. 


\section{FORKORTELSER}

ADCB: Arkivet ved Dansk Centralbibliotek for Sydslesvig

\section{KILDER}

Utrykte kilder:

ADCB F20-2 Den slesvigske Forening / Sydslesvigsk Forening. Bind 2, protokol over møder i folkerådet og fællesrådet 1939-46.

ADCB F108 Dansk Spejderkorps Sydslesvig. Pk. 2,1 korpsarkivet, diverse 1943-44. Pk. 5,1 protokol korpsrådsog førermøder 1942-45.

ADCB F280 Slesvig-Ligaen. Pk. 104,2 Dansk Skoleforening for Sydslesvig, rektor Bernhard Hansen 1943.

ADCB I61 Dansk Generalsekretariat, 03-10. Den danske folkegruppes civile krigsofre, bombeangrebet i Flensborg 19/5 1943, 1942-1943.

ADCB K4 Dansk Menighedspleje "Ansgar", Flensborg. Pk. 15 regnskaber vedr. forældrehjælpen m.v. 1936-46. Pk. 17 regnskab over forældrehjælp og ind- og udgåede varer 1939-42. Pk. 59 forhandlingsprotokol og fotos 1937-73.

ADCB P56 Jørgensen, Kai Ed. Jordt, 1906-84, og hustru Kirsten, født BuskRasmussen. Pk. 1 dagbogsuddrag og menighedssager 1938-45. Pk. 2 dagbøger og erindringer 1932-45.

ADCB P166 Christensen, L.P., redaktør Flensborg Avis 1882-1960. Pk. 29,29 Flensborghjælpen 1943-44. Pk. 41,8 notater og manuskriptkladder, talemanuskript 4-5/6 1943.

RA 7393 Gregers Carsten Larsen, Erindringer 1910-1984.

RA Flensborg, konsulær repræsentation, gruppeordnede sager (afleveret 1963) 1920-1945, 6.F.1.A.

SF IIC-00033 Bürgermeister/Stadtpräsident/Berichte über der dänischen Minderheit 1940-44. Bericht an den Herrn Regierungspräsidenten in Schleswig 14/10 1943. Ernst Schröder an den Herrn Regierungspräsidenten in Schleswig 12/4 og 8/10 1943.

SF VIIIG-00034 Kriegsauftragsverwal-
RA: Rigsarkivet

SF: Stadtarchiv Flensburg

tung/Luftschutz/Luftangriff am 19.5.1943. Diverse indberetninger.

Telefoninterviews 8.-13. januar 2014:

Søren Andresen, Hyllerup (spejder og kistebærer 24. maj 1943)

Karl Otto Meyer, Skovlund (spejder og kistebærer)

Christian Lorenzen, Flensborg (spejder og tilskuer)

Johann Nissen, Wees (spejder og tilskuer)

Trykte kilder:

Flensborg Avis, 29. oktober 1942: »Kredsleder Hans «.

Flensborg Avis, 2. november 1942: »Anna Petersens Jordefærd «.

Flensborg Avis, 22. maj 1943, s. 1: »Femten smaa Baarer «.

Flensborg Avis, 22.-24. maj 1943: diverse dødsannoncer.

Flensborg Avis, 24. maj, s. 1: „Saa rejser vi til vort Fædreland - «.

Flensborg Avis, 24. maj, s. 2: »Luftangrebets Ofre" .

Flensborg Avis, 24. maj-11. juni 1943: diverse kondolencer.

Flensborg Avis, 25. maj 1943, s. 1-2: »Jordefærden ved Fredshøjen «.

Flensborg Avis, 27. maj 1943: »Dansk Fællesskab «.

Flensborg Avis, 28. maj 1943: "Af et Brev «.

Flensborg Avis, 29. maj 1943: »En Mindestund $«$.

Flensborg Avis, 2. juni 1943: »15 smaa Kister «.

Flensburger Nachrichten, 20. maj 1943, s. 3: »Luftangriff auf Flensburg «.

Flensburger Nachrichten, 21. maj 1943, s. 3: »52 Gefallene«.

Flensburger Nachrichten, 21.-24. maj 1943: diverse dødsannoncer.

Flensburger Nachrichten, 24. maj 1943, s. 
3: »Flensburg nahm Abschied von seinen Toten «.

Flensburger Nachrichten, 25. maj 1943, s. 3: »Totenfeier am Friedenshügel«; »Eine ergreifende Trauerfeier «.

Fröhlich, Elke (udg.): Die Tagebücher von Joseph Goebbels. 1993, Band 7 og 8.

Grænseforeningen: Beretning om Sendemandsmødet 1944 i København. 1944.

Michaelis, Herbert og Ernst Schraepler (udg. og red.): Ursachen und Folgen: Vom deutschen Zusammenbruch 1918 und 1945 bis zur staatlichen Neuordnung Deutschlands in der Gegenwart, 19. bind, kilde 3330 , s. 263-64.

Nationaltidende, 23.-24. marts 1945: diverse dødsannonceringer.

\section{LITTERATUR}

Achton, Peter: Jeg har båret lærkens vinge ... Johanne Hansens livseventyr. København 1975, s. 78-99.

Ahlmann, Henrik: Den Franske Skole: RAF's angreb på Shellhuset 21. marts 1945: En kortlægning af katastrofen på Frederiksberg og Vesterbro. 2005.

Andresen, Søren: »Min 19. maj«, Sydslesvigsk Forening for Flensborg amt: Julen 2010. Flensborg 2010, s. 6-9.

Bogensee, J.: »Danske i sorg: Indtryk fra et besøg i Sydslesvig ", Grænselandet, nr. 6-7, juni-juli 1943, s. 5-6.

Busk Petersen, Anders: »Æselspark og myggestik ", Wingender, Frans m.fl. (red.): Duborg-skole-elever i krigens år. Flensborg 1990, s. 75-79, 144.

Dansk Skoleforening Flensborg 1942-43. Aarsberetning Nr. 21, s. 73-75.

Dansk Spejderkorps Sydslesvig: 1919 - 10. August - 1944. Flensborg: Korpsraadet.

Duggen, Harald: »Harreslevmark Duborg-banke", Wingender, Frans m.fl. (red.): Duborg-skole-elever i krigens år. Flensborg 1990, s. 28-41, 141.

Ernst, Gerhard: "Digte og erindringer«, Wingender, Frans m.fl. (red.): Duborg-skole-elever $i$ krigens år. Flensborg 1990, s. 42-49, 142.

Futtrup, Hans M.: »Korsvej mellem nødvendighed og frivillighed «, Wingender, Frans m.fl. (red.): Duborg-
Nationaltidende, 28. marts 1945: »Den katolske Kirkes Farvel til Ofrene«.

Nationaltidende, 29. marts 1945: „Sjælemessen for de 8 Nonner «.

Ravneskriget: Spejderblad for Dansk Spejderkorps Flensborg, 1.-5. Aargang, 1933-1937.

Internettet:

http://www.1000dokumente.de/?c= dokument_de\&dokument $=0200$ goe\&object $=$ translation $\& \mathrm{l}=$ de: $\mathrm{J}$. Goebbels tale i Sportpalast 18. februar 1943.

skole-elever $i$ krigens år. Flensborg 1990, s. 13-21.

Futtrup, Hans M.: »Korpset fra 1942 til 1952«, Dansk Spejderkorps Sydslesvig: 1919 - 10. August - 1969. Flensborg 1969 , s. 30-37.

Hansen, Bernhard: At sejle er nødvendigt. Flensborg 1971.

Hansen, Bernhard: „15 børnegrave som næppe nogen andre: En rædselsdag over Flensborg for 25 år siden«, Flensborg Avis, 17. maj 1968, s. 5,16 .

Halvas, Hugo: »Med Duborg-skolen som hverdagsstøtte", Wingender, Frans m.fl. (red.): Duborg-skole-elever $i$ krigens år. Flensborg 1990, s. 112$129,142$.

Henningsen, Lars N. (red.): Sydslesvigs danske historie. 3. udg. Flensborg 2013, s. 355-56.

Hüpfel, Anni: „Den 19. maj 1943«, Wingender, Frans m.fl. (red.): $D u-$ borg-skole-elever $i$ krigens år. Flensborg 1990, s. 80-84, 143.

Johnsen, Axel: »Bomber over Batterigade«, Flensborg Avis, 15. maj 2003, s. 16.

Jørgensen, K.E. Jordt: Tolv Aar i Sydslesvig. København 1948.

Kallis, Aristotle A.: Nazi Propaganda and the Second World War. Hampshire og New York 2008.

Kirwin, Gerald: »Allied Bombing and 
Nazi Domestic Propaganda «, European History Quarterly, 15. årg., 1985, s. 341-362.

Kronika, Jakob: Midt i fjendens lejr: Slesvigske dagbogsblade fra Hitler-krigens Berlin. København 1966.

Meyer, Karl Otto: Frihed, lighed og grænseland: Erindringer. Gentofte 2001.

Meyer, Karl Otto: »Hans Munk Futtrup«, Sønderjysk Almanak, 4. årg., 1997, s. 115.

Noack, Johan Peter: Det danske mindretal $i$ Sydslesvig 1920-1945. Aabenraa 1989, s. 457-531.

Nygaard, Jens: »Dengang bomber dræbte danske børn ", Flensborg Avis 18. maj 2013, s. 22-23.

Petersen, H.F. I Krig og Fred. København 1946.

\section{NOTER}

1. Jørgensen 1948, s. 48.

2. Schwensen og Nickel 2008, s. 126-50.

3. Kallis 2008, s. 131.

4. Michaelis og Schraepler, s. 263-64.

5. http://www.1000dokumente.de/ $? \mathrm{c}=$ dokument_de\&dokument $=$ 0200_goe\&object $=$ translation $\& \mathrm{l}=$ de.

6. Kirwin 1985 , s. 341-44.

7. Ibid, s. 345-53.

8. Flensburger Nachrichten 20.5.1943, s. 3.

9. Ibid. 21.5.1943, s. 3.

10. Ibid. 24.5.1943, s. 3.

11. Flensborg Avis 24.5.1943, s. 2.

12. Flensburger Nachrichten 24.5.1943, s. 3.

13. Schwensen og Nickel 2008, s. 127.

14. Kronika 1966, s. 252.

15. Hansen 1971, s. 95-96.

16. Ibid., s. 96.

17. Flensborg Avis 25.5.1943, s. 1.

18. Kronika 1966, s. 248.

19. Fröhlich 1993, Band 7, s. 460.

20. Flensburger Nachrichten 25.5.1943, s. 3.

21. Flensborg Avis 25.5.1943, s. 1.

22. Gengivet i sin fulde ordlyd i Flensborg Avis 24.5.1943, s. 1.

23. Flensborg Avis, 25.5.1943, s. 2.

24. RA, Flensborg, konsulær repræsentation, gr. sager (afl. 1963) 19201945, 6.F.1.A, konsul Ryder 27.5.
Rasmussen, René: »Under verdenskrigen 1939-1945«, Henningsen, Lars N. (red.), Sydslesvigs danske historie. Flensborg 2009, s. 164-76.

Rasmussen, René: »Jacob Kronika i Berlin 1939-1945«, Grenzfriedenshefte, 2002, 1, s. 25-42.

Rostgaard Nissen, Mogens: »De første årsmøder efter Anden Verdenskrig «, Flensborg Avis, 8. juni 2013, s. 20.

Svensson, A.: »Dansk Samraad«, Sønderjydske årbøger 1951, s. 1-113.

Schwensen, Broder og Dieter Nickel: Flensburg im Luftkrieg 1939-1945. Flensburg 2008, s. 125-50.

Wadskjær Nielsen, Sune: Holmenkatastrofen. Eget forlag 2008.

1943; Dansk Skoleforenings beretning 1942/43, s. 73-74, Kronika 1966 , s. 250-52.

25. Hansen 1971, s. 94.

26. Flensborg Avis 29.10.1942.

27. Ibid. 2.11.1942.

28. Jørgensen 1948, s. 45.

29. Hansen 1971, s. 94.

30. SF IIC00033, brev af 8.10.1943.

31. RA, Flensborg, konsulær repræsentation, gr. sager (afl. 1963) 1920-1945, 6.F.1.A, konsul Ryder 27.5.1943.

32. P166-41,8: manuskript 4.6.-5.6.1943, s. 21.

33. Hansen 1968, s.16.

34. Hansen 1971, s. 94.

35. Ibid.

36. Kronika 1966, s. 248.

37. RA, Flensborg, konsulær repræsentation, gr. sager (afl. 1963) 19201945, 6.F.1.A, konsul Ryder 27.5. 1943.

38. Futtrup 1990, s. 20.

39. ADCB P166-41,8: manuskript 4.6.5.6.1943, s. 21.

40. Nielsen 2008, s. 3-4.

41. Ahlmann 2005, s. 165; Nationaltidende 28.3.1945.

42. RA, Flensborg, konsulær repræsentation, gr. sager (afl. 1963) 1920-1945, 6.F.1.A, konsul Ryder 27.5.1943.

43. Flensborg Avis 25.5.1943, s. 1. 
44. Dansk Skoleforening Flensborg 1942-43, s. 74.

45. ADCB K4-15 regnskab forældrehjælp.

46. Achton 1975, s. 83.

47. Flensborg Avis 25.5.1943, s. 1.

48. ADCB P56-2, erindringer s. 94.

49. Dansk Skoleforening Flensborg, årsberetning 1942/43, s. 74.

50. Hansen 1968, s. 16.

51. Hansen 1971, s. 94.

52. Dansk Spejderkorps Sydslesvig 1919-44, s. 7.

53. Ernst 1990, s. 47.

54. Futtrup, 1990, s. 20; Meyer 2001, s. 54.

55. Duggen 1990, s. 36, 141.

56. Futtrup 1969, s. 34.

57. Meyer 2001, s. 54.

58. Futtrup 1990, s. 20.

59. Hansen 1968, s. 16.

60. Futtrup 1990, s. 20.

61. Meyer 2001, s. 54.

62. Andresen 2010, s. 9.

63. Busk Petersen 1990, s. 76.

64. Ravneskriget 1933, nr. 2, s. 6.

65. SF IIC-00033, brev af 8.10.1943.

66. Flensborg Avis 25.5.1943, s. 2.
67. F.eks. Hansen 1968, s. 16; Halvas 1990, s. 119; ADCB P166-41,8, L.P. Christensen 4.6.-5.6.1943, s. 21; ADCB F20-2, Folkerådets protokol, s. 115; Bogensee 1943, s. 5.

68. Henningsen 2013, s. 355.

69. Rostgaard Nissen 2013.

70. Henningsen 2013, s. 356.

71. Flensborg Avis 22.5.1943, s. 1.

72. SF CII 00033, brev af 12.4.1943.

73. ADCB F20-2, s. 108.

74. ADCB F280-104,2, brev af 29.5. 1943; ADCB F20-2, s. 117.

75. Jørgensen 1948, s. 47.

76. RA 7393. s. 28.

77. Hansen 1968, s. 16.

78. Ravneskriget januar 1937, s. 1.

79. Hüpfel 1990, s. 83; se også Halvas 1990, s. 119.

80. Flensborg Avis 27.5.1943.

81. Ibid. 28.5.1943.

82. Ibid. 29.5.1943.

83. Ibid. 2.6.1943.

84. Svensson 1951, s. 80.

85. ADCB P166-29,29; Grænseforeningen 1944, s. 33.

86. Jørgensen 1948, s. 48.

\section{Zusammenfassung}

Am 19. Mai 1943 wurde Flensburg einem schweren amerikanischen Luftangriff ausgesetzt, der 82 Menschen das Leben kostete, 24 von ihnen gehörten der dänischen Minderheit an. Der größte Teil der Opfer wurde fünf Tage später bei zwei großen gemeinsamen Bestattungen, eine für die deutschen Opfer und eine für die dänischen, auf dem Friedenshügel in Flensburg beigesetzt. Die erste Zeremonie wurde durch die nationalsozialistische Ortsleitung, die andere durch die Leitung der dänischen Minderheit veranstaltet. Später wurden die Begräbnisse sehr unterschiedlich interpretiert, es gab auch deutliche Unterschiede, gab es aber auch gemeinsame Züge? In diesem Artikel werden Ähnlichkeiten und Unterschiede im Verlauf der Veranstaltungen untersucht und die Hintergründe analysiert. Es wird festgestellt, dass die deutsche Zeremonie mit den Propagandastrategien, die durch Goebbels' Propagandaministerium festgelegt wurden, gut übereinstimmte. Auch die dänische Zeremonie, überwiegend mit religiösem Charakter, zeichnete und verbreitete ein positives Bild der nationalen Minderheit, welches sie in der aktuellen Lage unterstützte. 